\title{
WAVERING BETWEEN TWO WORLDS: THE BORDERLINE CUTTING THROUGH NELIDA MILANI'S ISTRIA
}

\section{GREGORIA MANZIN}

\begin{abstract}
Sommario
Sulla scia della rinnovata attenzione dedicata al caso istro-dalmata in seguito all'istituzionalizzazione del Giorno del Ricordo (celebrato annualmente, a partire dal 2005, in data 10 febbraio a commemorazione della firma del trattato di Parigi nel 1947), quest'articolo prende in esame il confine, e nella fattispecie il confine tra Slovenia e Croazia: un nuovo "taglio" che nel 1991 lacerò ulteriormente il già provato tessuto sociale della terra istriana. Il confine è qui visto attraverso la rappresentazione allegorica che ne dà Nelida Milani, autrice istriana nata e residente a Pola (Pula).

L'astrazione della "linea di confine" viene presa in esame creando un parallelo tra l'interpretazione geopolitica del termine, come "zona di passaggio", ed una sua interpretazione antropologica, in quanto "fase di passaggio". Agli occhi della scrittrice Nelida Milani, qui la vita pare essere rimasta intrappolata all'interno di questa zona-fase di passaggio: non più parte del territorio italiano ormai da decenni, il crollo del sogno socialista di Tito sembra aver drammaticamente rinnovato ed esasperato l'isolamento di chi è stato, e già era stato in passato, preso nel mezzo.
\end{abstract}

The literary work of Istrian born writer Nelida Milani is well known not only among the Italian ethnic community residing in Istria and Dalmatia, but also on a wider national scale, especially thanks to two books which received considerable attention at the time of their publication: Una valigia di cartone (1991) and Bora (1998).

Milani was born in Pola (Pula) in 1939. Today part of Croatia, Pola used to be part of Yugoslavia before the collapse of Tito's socialism. 
This town is one of many which were handed over to the former Yugoslavia in accordance with the 1947 Paris Peace Treaty signed at the conclusion of WWII. Milani has always lived in her hometown. Beyond her activity as a scholar at the local university ${ }^{1}$, in 1991 she published Una valigia di cartone. A less known bilingual (Italian and Serbo-Croatian) collection of short stories followed in 1994: L'ovo slosso/ Trulo jaje was jointly published by Edit (Fiume - Rijeka) and Durieux (Zagreb). Her most recent work, Bora (1998), was coauthored by another Istrian born writer, the Rome-based journalist Anna Maria Mori. 'Una valigia di cartone' is the title of the first of two long stories included in the work published under the same name. This tale was awarded first prize in the narrative section at the Concorso Istria Nobilissima in 1990. The second story in this volume, 'Impercettibili passaggi', won the same prize the year before. However, it was only when the two tales were published together by the Palermitan Sellerio that Nelida Milani truly hit the readership on a national scale and was awarded the Premio Mondello (opera prima).

Una valigia di cartone is not the only work for which Milani received an award. Milani and Mori's Bora, an exchange of letters between the two writers which centres on the dramatic topic of the Istro-Dalmatian exodus, was awarded several prizes and attracted national interest. Commenting on these letters, Irene Visintini writes:

Due destini di frontiera [...] quelli di Anna Maria Mori e di Nelida Milani, specchio e somiglianza di una condizione subíta da migliaia di altre persone, che in un momento come il nostro, fatto di desideri di globalizzazione, ma anche di opposizioni e tendenze separatiste e di spaventosi conflitti, diviene la parabola, il simbolo di un destino che ha colpito in passato e continua a colpire tante popolazioni, nelle parti diverse del globo ed è quindi di estrema attualità. (Visintini 2004:226)

1 See the publications: Milani Kruljac e Orbanić 1989, and Milani Kruljac 1990. 
It is precisely because of the many existing examples of this kind of situation, namely the shifts of geo-political borders between neighbouring nations, that the Istro-Dalmatian case acquires even more relevance. The exodus which followed the 1947 Peace Treaty, together with its consequences on the local ethnic Italian community, is one of the numerous changes which came to seriously affect the internal socio-political scenario of the $\operatorname{area}^{2}$. However, this situation is relevant not only within the specificity of the social, political and cultural Italian context, but also on a much wider and global degree, since it speaks for a phenomenon which is far from rare in modern society.

In this paper I will focus on 'Capre', one of the short stories in the collection L'ovo slosso/ Trulo jaje. This tale offers the possibility of analysing Milani's point of view regarding the consequences that the multiple shifts of the eastern Italian border have had on the ethnic Italian population residing in this area. Istria was firstly excluded from the Italian territories after WWII, and later partitioned between the young republics of Slovenia and Croatia after their declaration of independence from the former Yugoslavia in 1991. I will argue here that a major effect of these geo-political changes is clearly observable in the way Milani portrays the shaken sense of national belonging experienced by the population affected by the shifting of the borderline. However, despite the drastic wound that such a shift cut into the sentiments of national belonging of the local ethnic Italian population, Milani suggests that the attachment to the native sociocultural roots remains unshaken and it becomes in fact the very element through which this community can hold on to its own identity.

2 Italian historic and political studies estimate that roughly 350.000 ethnic Italians left their native provinces of Istria and Dalmatia as a consequence of the 1947 Paris peace treaty. See Petacco 1999 and Oliva 2005. 
My approach to this analysis relies on an understanding of the border as a space-time of 'liminality'. The understanding of this term unfolds on two different levels: on the one hand, 'liminality' will be looked at in its spatial implications, a perspective brought up by the fact that the border can be interpreted as a space of transit, thus a 'liminal space'. On the other, this specific conception of the border will lead to considerations on the 'stage of liminality', a temporary phase associated with the crossing of this kind of space. In support of my argument, I will draw from studies conducted in two different disciplines: geography and anthropology. I use the seminal work of geographer J.R.V. Prescott to examine developments in the understanding of the concept of border. Among the various studies mentioned by Prescott, of particular interest for the current paper is Friedrich Ratzel's notion of "border fringe" (Prescott 1978:14). The second element used to establish the theoretical groundings for this analysis comes from the work of anthropologist Arnold van Gennep. Although not recent (originally published in French in 1908), van Gennep's analysis is still considered a fundamental study on liminality by scholars in the field, as proved by continued sustained reference to his book The Rites of Passage (1960).

In the short story 'Capre', Milani takes up the topic of the border, although the theme is here tackled from an ironic and yet quite symbolic perspective. The narration opens with the start of the works to build the new border between Slovenia and Croatia. One of the inhabitants of the area where the new border is being built complains to the director of the site, because the old path leading to his village has been closed as a consequence of the construction works: "La vita del villaggio dipende da esso: i nostri morti lo percorrono quando partono per sempre e i nostri esuli lo usano quando tornano a casa. Ma soprattutto si tratta del sentiero che le capre prendono per venire al mondo [...]" (Milani 1994:59). The director of the site, signor Cervar, listens to the complaints of the old man "con un sorriso bonariamente ironico sul volto" (Milani 1994: 59). He points out that the purpose of the border "è proprio di sradicare credenze come questa" (Milani 
1994:59). Dead people do not need paths and the idea that the esuli would come back is almost absurd. As for the goats, he continues, it is quite ridiculous to believe that they need a path to be born.

With these comments signor Cervar dismisses the old man, who warns, before leaving, that, unless the old path is reopened, there will be unpleasant consequences. The border is finished and the old path remains closed. After the initial curiosity surrounding the event that, with its invisible line, came to cut through the familiar landscape but also the private (the stable and also a big yellow house) and the public spaces of their social lives (the soccer field and the osteria), the local inhabitants lose interest in this novelty and go back to their usual routines. The only difference is that now their daily life is scanned by the sentence "il confine è una disgrazia" (Milani 1994:60).

One day a goat appears on the neutral territory in front of the traffic light regulating the flux of cars proceeding towards the border. It makes its way in front of the glass beyond which the custom officers wait to check the documents of the travellers and it reaches the little room of the border complex. Here it defecates, before leaving unhurriedly "non come una ladra, ma piuttosto come una che sia venuta a cagolare sul suo" (Milani 1994:61). This situation is repeated the day after. The fourth day, after the failed attempts of the two previous days, one of the officers runs after it and shoots it dead. On the fifth day a second goat appears on the border. At the end of the story, the readers learn that forty goats have already been killed when the inspector called to report over the situation writes a letter lamenting the existence of a "guerra tribale" (Milani 1994:63) between customer officers and goats. After sending the report back to the capital city, the inspector ponders over a possible strategy that could save the goats from being killed but he cannot think of any such strategy. Will another one make its appearance? "Quell'essere gli risultava adesso come una personificazione, racchiudente il segreto stesso di quella terra" (Milani 1994:63). The short story ends with the forty-first goat appearing on the platform of the border complex. 
Earlier, in my presentation of this short story, I used two adjectives: 'ironic' and 'symbolic'. The irony is traceable in the absurd situation of the guerra tribale between officers and goats, with the animals disturbing the officers' work with their daily ritual of defecating right on the border premises. The adjective 'symbolic' reminds the readers of the fact that this short story is centred on a specific symbol: the goat. The goat is in fact the main feature of the coat of arms of the Istrian region ${ }^{3}$, and a reading of the tale according to this symbology is actually supported by the inspector's view of the goat as the personification of the land of Istria. If we accept this first parallel, it is then possible to proceed with an interpretation of the whole story that follows the symbolic line introduced by the reference to the goat.

In this respect, it is important to remember that, according to the old man complaining to signor Cervar at the beginning of the tale, the path that has been closed as a consequence of the construction of the border, is in effect the one that brings the goats into life, as well as the one used by the dead after their passing away and by the esuli to come back to their own land. It is important here to note that all the functions carried out by this path coincide with 'liminal phases', therefore the path itself can be considered a 'liminal space'.

A key consideration follows the two points just made: the path has been closed to prop up the division of the land enacted through the construction of the border, and the border now represents the only gate of connection between two sides which are now separated. We know that signor Cervar suggested the old man open a new path, parallel to the old one, but simply shifted to the side, so that it would be consistent with the new geography imposed by the border. The old path had to be closed because it ended in the neutral land of the border

3 The figurative solution of the coat of arms, officially adopted by the Regional Assembly on the $1^{\text {st }}$ of July 2002, is based on one of the historic coats of arms of Istria from the IX century. The flag is divided in two horizontal sections, one blue and one green, with the coat of arms in the middle. Blue stands for the Istrian sky and sea while the green symbolizes the Istrian interior. 
itself, a territory that cannot be properly considered part of any state because it belongs to the transit zone separating the two states. In this sense, we can consider the border itself as a liminal space. The old path is a liminal space by virtue of the functions attributed to it by the local inhabitants and it can be considered a liminal space in its role of gateway between two adjacent nations. The link between the two is represented by the fact that the liminal space of the old path leads to (or ends in, or eventually begins from) the liminal space of the border. Let me here make a brief digression in order to explain how my understanding of the border as a transit area is consistent with the views of several geographers who have incisively contributed to the debate on the concepts of border, boundary and frontier.

In the introduction of his work Boundaries and Frontiers (1978), J.R.V. Prescott presents a concise summary of the literature in the field, concentrating on nine authors whose works were published between 1897 and 1945. The first name mentioned by Prescott is Friedrich Ratzel, who taught geography at the University of Leipzig until 1904. Illustrating Ratzel's view on the border, Prescott writes:

Ratzel's border fringe, which can be abbreviated to border, consisted of three zones, two of which were the periphery of adjoining states, while the third was a central zone where there was a mingling of the characteristics and authority of the two states. (Prescott 1978:14)

After examining the position of several other geographers ${ }^{4}$, Prescott remarks that they all seem to build on "the accepted idea that the

\footnotetext{
In 1928, P. De Lapradelle published a book which built on the concept of the tripartite border developed by Ratzel. Prescott underlines that, being De Lapradelle a lawyer, he was interested in borderlands from the perspective of international law. De Lapradelle considered the frontier as "an environment of change" and suggested a division that followed Ratzel's original idea: "The central region is styled territoire limitrophe by Lapradelle, and this is the area where international law may apply. [...] The political flanking areas are called frontières and are subject to the internal laws of the states concerned. The total area of these three zones is called le voisinage - borderland" (Prescott
} 
boundary is a line within a borderland" (Prescott 1978:23). At the end of his introduction, Prescott points out:

$[O]$ ne of the concepts which have been generally accepted is that the boundary must be considered in its territorial context. This view started with Ratzel, who saw the boundary as an abstraction and the boundaryzone as the reality, and has been continued. (Prescott 1978:29)

If we move back to Milani's short story, the space where the goats make their appearance, disturbing the work of the custom officers, is in fact what Prescott calls, in this last quote, the boundary-zone. It is in this sense that I have referred to it as a liminal space: far from coinciding with the boundary itself, it rather indicates an area, the borderland, "the transition zone within which the boundary lies" (Prescott 1978:31). These considerations on the nature of the borderland could be applied to examine the function attributed to the old path. This can also be considered as a space of transit to reach further destinations (life for the goats, the after-life for the dead, and the village - the past? - in the case of esuli). Yet, since the functions ascribed to the old path actually infer a status of transitoriness, it seems here appropriate to shift slightly our perspective and consider the whole situation from a time-space perspective.

What I am suggesting here is the possibility of carrying out an analysis that looks at the old path not only as a 'space' of transit, but also as a 'time' of transit: in other words, I am shifting the attention to the liminal condition of the 'phase' associated with the act performed through the path (birth, death and the return).

1978:21). A third important name that contributed to the acceptance of this view is recognized in Jacques Ancel, according to whom "the boundary reflects the relationships between neighbouring groups and should be studied to this end rather than a single element of the landscape" (Prescott 1978:23). 
This parallel between the temporal and the spatial dimension is one underlined also by Arnold van Gennep in one of the introductory chapters of his work The Rites of Passage. Here van Gennep points out how "[t]erritorial passages can provide a framework for the discussion of rites of passage" (van Gennep 1960:15), an analysis that he then carries out in the following chapters of his work. The three constituting phases of the rite of passage recognized by van Gennep are 'separation', 'transition' and 'incorporation'. Such a classification runs in parallel with the tripartite concept of the "border fringe" advanced by Ratzel. More precisely, the rite of passage as a whole is understood as composed of three different phases to which specific rites are associated: pre-liminal rites are "rites of separation from a previous world", liminal rites are "those executed during the transitional stage", and post-liminal rites are "ceremonies of incorporation into the new world" (van Gennep 1960:21). Indeed, the practices symbolized by these three stages - 'separation', 'transition' and 'incorporation' - could be applied to describe the passage through the areas forming Ratzel's "border fringe".

Let us now return to the examination of the symbolic meaning attributed to the old path of Milani's short story. Van Gennep declares his interest in "the magico-religious aspect of crossing frontiers" (1960:15) and underlines that the process of crossing such a frontier is associated with a status of wavering between two worlds. This is what he refers to with the term 'transition'. In this sense, in the case of the goats, the old path of Milani's tale represents the space-time transit into existence. Once the goats appear on the border, we know that they have already walked the path through to its end. With the border now being located at the end of the path, we can conclude that the border itself coincides, spatially and temporally, with the goats' moment of 'being into existence': the process of 'coming into life' is concluded and they now find themselves in existence. It follows that the liminal space-time defined by the border and the old path do not perfectly match: they overlap each other in their space collocation (with the path terminating on the border) and therefore the liminal spatio- 
temporal segment of the border does not bear any meaning for the animals, whose magico-religious birth is granted through a different liminal spatio-temporal passageway.

These considerations need now to be read according to the initial symbology in Milani's tale. As the inspector suggested, the goats appears as "una personificazione, racchiudente il segreto stesso di quella terra". From this perspective, following the previous lines of analysis, this short story can be read as an allegory for the condition of existence of those involved in the process of the definition of the new borders. After the first "lunga e frastagliata rottura" imputed to the exodus (Milani e Mori 1998:11), Milani highlights how the healing of the wound has been obstructed by a second fracture identified in the further separation caused by the creation of the border between Slovenia and Croatia:

La ferita si è riaperta nel corpo stesso della terra. È un taglio nella collina alle spalle di Castelvenere, o meglio, due tagli fra Slovenia e Croazia, sul fiume Dragona e a Spicciole. Un lungo e inutile confine impastato di nuovi afrori coloniali [...]. Ogni volta che devo attraversarlo, fra i camion e la squadera di una gru rossa sulla strada sterrata fra i tornanti stretti, mi sento imbrattata di rabbia e di impotenza. Una irritazione sorda, una ripugnanza rancorosa, cattiva. Mi vien voglia di prendere un sedativo per premunirmi dall'infiammazione cerebrale, invece allungo il passaporto e mentre il graffio di emozione si trasforma in spasmo allo stomaco, continuo a mormorare con una risatina un poco folle che tutto va nel migliore dei modi... [...]. I sindaci istriani hanno pregato i governi di lasciare il confine così com'era sotto la Defunta. Secchi rifiuti. Ma non poteva essere diversamente. Per quanto possa sembrare paradossale, questo è il nuovo segno speculare della debolezza dell'identità nazionale di questi nuovi Stati. Soltanto nazioni sicure di sé, sicure delle proprie ragioni storiche, si sarebbero potute 
riconoscere positivamente in forme di confini leggere ed effimere, "soft", come usa dire oggi. (Milani e Mori 1998:12-13)

Similar to the old man at the beginning of the story, the mayors of the Istrian towns asked to maintain the border as it was under exYugoslavia. As in the tale, the administrations responsible for the decision refused to accept this request.

In light of this passage quoted from Bora, I would like to draw attention to the almost scoffing behaviour of the goats in the tale. My use of the adjective 'scoffing' comes from the knowledge of the historical and socio-political situation implied by this short story. Ignoring such a situation, the behaviour of the animals would appear as an element of comedy more than irony, as I instead chose to define it. Only being aware of Milani's sentiments towards this new border is it possible to read a mocking attitude in the behaviour of these animals. Such a behaviour is indeed not feasible for the author, who simply hands her passport to the custom officer. Such an act is however marked by an almost silent risatina folle.

In conclusion, the allegory constructed throughout this tale seems to point to the state of liminality into which the Istrian inhabitants have been thrust as a result of the imposition of the new borders. However, in this case the liminal situation is not perceived as a temporary phase, it does not indicate a moment of transition. The border is here to stay and the local inhabitants have to come to terms with the new reality of things. In this sense, the behavioural patterns followed by the goats (and here the goats are to be viewed as a symbol of the Istrian people) suggest that the only possible outcome of the situation is indeed the continuation of the usual life patterns ${ }^{6}$.

Italics is used in this work to signal the parts written by Milani.

6 Even if the goats get shot, they continue to appear on the border day after day. Luciano Dobrilović suggests that, in this sense, the goats can be seen as representing "il sacrificio dell'innocente, di fronte al quale l'uomo si ostina a non voler capire" (Dobrilović 2004:359). 
Obviously the existence of the border cannot fail to be noticed. However, on a practical side, the only apparent effect of this change is the sentence, "il confine è una disgrazia".

Like Milani's own act of simply passing her passport to the officers when crossing the border, on a superficial level the situation appears to be accepted. However, the sentence "il confine è una disgrazia", together with Milani's reference to the risatina folle, suggests that the border has in effect inflicted a new rupture into the already wounded flesh of this peninsula and its inhabitants. The new border seems to have trapped the Istrian people in a transitional stage where they remain isolated, compounding the sense of solitude already perceived as a consequence of the geographical redistribution of these territories imposed by the 1947 Peace Treaty: "L'esilio interno continua, la solitudine dell'Istria continua..." (Milani e Mori 1998:13) ${ }^{7}$.

Nevertheless, Milani seems to point to the inescapability of holding onto one's own roots, looking at these borders as exemplifications of political disputes between young and fragile nations. Socio-cultural awareness is the result of long rooted traditions which cannot be easily modified by a new "invisible line", one that separates what until then had been part of a united entity. The practicalities of daily routines will have to be adjusted according to the new parameters imposed from above (parameters which in fact ignore the status quo which they have drastically disrupted), but il "segreto stesso di quella terra" will endure. Politics can indeed change the outside aspects of social aggregation but any effort in changing rooted habits, traditions, social practices and modes of social exchange cannot be fully accomplished in the span of one generation.

\footnotetext{
The sense of entrapment in a liminal space is underlined also by another Istrian writer Fulvio Tomizza, in his novel Il sogno dalmata: "Allo scadere dei termini dell'esodo feci un ragionamento inverso: l'anima delle cose, dei luoghi, dei ricordi, si era trasferita di là, stava dall'altra parte. E partii, sapendo o soltanto temendo di collocarmi per sempre in uno spazio di mezzo, neutro e impervio, nel quale molte volte mi sarei sentito estraneo anche a me stesso" (Tomizza 2001:56).
} 
The goats, symbolizing the primordial spirit of Istria, appear then to act in response to the only rules they have ever known and followed. This is a privilege not granted to human beings, whose life is regulated through economic and socio-political structures within which individuals have to find their own space. Nonetheless, through this short story, Milani suggests that, although such socio-political structures have been modified, the Istrian people will not abandon their modus vivendi simply to subscribe to disputes between two emerging states. Even if further isolated, these communities will continue to operate according to the traditional socio-cultural practices in use until the time of excision, regarding new geo-political solutions with a certain contempt and regret.

In this perspective Milani's comment previously quoted from Bora, "la solitudine dell'Istria continua", becomes even more significant: in Milani's eyes Istria appears to be constricted within a space-time of transition. On a geo-political level these territories are now part of Croatia and Slovenia, however the local ethnic Italian inhabitants still follow their native social customs, which are rooted in cultural traditions, specifically Italian ones:

Alzò gli occhi verso il bosco ed ecco una piccola figura bianca muoversi con magre natiche sul gomito della pensilina. Non è un'illusione ottica, non sparisce, è una capra avvolta nel suo bianco scialle magico. Il cuore cominciò a battergli. (Milani 1994:63)

With these lines Milani closes her short story, concluding that more than ever before Istria lives in solitude, yet the white Istrian goats go on living the way they always have.

(Swinburne University of Technology) 


\section{Bibliography}

Dobrilović, L.

Milani, N.

Milani, N.

Milani, N. \&

Mori, A.M.

Milani Kruljac, N.

Milani Kruljac, N. \& Orbanić, S.

Oliva, P.

Petacco, A.

Prescott, J.R.V.

Tomizza, F.
2004 Inconscio collettivo e personale nella narrativa di Nelida Milani e nella poesia di Laura Marchig e Marianna Jelicich. In: Deghenghi Olujić, E. (ed.) La forza della fragilità. Fiume-Rijeka: Edit:354-370.

1991 Una valigia di cartone. Palermo: Sellerio.

1994 L'ovo slosso/ Trulo jaje. Fiume-Rijeka \& Zagreb: Edit/Durieux.

1998 Bora. Milan: Frassinelli.

1990 La comunità italiana in Istria e a Fiume. Fra diglossia e bilinguismo. Trieste and RovignoRovinj: Centro di Ricerche Storiche di Rovigno, Unione degli Italiani dell'Istria e di Fiume, Università Popolare di Trieste.

1989 Italofonia nel triangolo istroquarnerino. In: Padoan, G. \& Bernardi U. (eds.) Il gruppo nazionale italiano in Istria e a Fiume oggi. Una cultura per l'Europa. Venice: Longo.

2005 Profughi. Dalle foibe all'esodo: la tragedia degli italiani d'Istria, Fiume e Dalmazia. Milan: Mondadori.

1999 L'esodo. La tragedia negata degli italiani d'Istria, Dalmazia e Venezia Giulia. Milan: Mondadori.

1978 Boundaries and Frontiers. London: Croom Helm.

2001 Il sogno dalmata. Milan: Mondadori. 
van Gennep, A.

Visintini, I.
1960 The Rites of Passage. Chicago: The Chicago University Press.

2004 Storia, poesia e memoria in Isabella Flego, Loredana Bogliun, Nelida Milani, Anna Maria Mori, Laura Marchig, Lina Galli e Elsa Bragato. In: Deghenghi Olujić, E. (ed.), $L a$ forza della fragilità. Fiume-Rijeka: Edit: 211-236. 